\title{
Facile solvent-free one-pot synthesis of pyranobenzopyrans and their derivatives
}

\author{
P SIRISHA, SUHAS PEDNEKAR*, ANANT R KAPDI and MINAL NAIK \\ Organic Chemistry Research Laboratory, Ramnarain Ruia College, Matunga, Mumbai 400 019, India \\ e-mail: pednekarsuhas@gmail.com
}

MS received 9 December 2010; revised 8 May 2011; accepted 30 May 2011

\begin{abstract}
The condensation of hydroxyl coumarins in a facile one-pot procedure with active methylene esters to afford novel benzopyrans under solventless conditions is described. The products underwent further condensation and cyclization reactions to form novel heterocycles.
\end{abstract}

Keywords. Dimethylacetone-1,3-dicarboxylate; pyranobenzopyrans; 4-hydroxycoumarins; solvent-free.

\section{Introduction}

Coumarin derivatives have revealed promising biological activity with interesting potential in therapeutic application ${ }^{1}$ besides their traditional use as anticoagulants, ${ }^{2}$ antifungal, ${ }^{3}$ anti-inflammatory agents, ${ }^{4}$ etc. They have also shown important property as antibiotics (novobiocin and analogs), ${ }^{5}$ anti-AIDS agents (calanolides $)^{6}$ and antitumor drugs. ${ }^{7,8}$ Benzopyrans form an important class of coumarin derivatives known for their diverse biological activities. ${ }^{9-12}$ The biological importance and the therapeutic action of benzopyrans have generated a lot of interest over the years. A thorough literature survey revealed that condensation of various active methylene groups on 4-hydroxycoumarin ${ }^{13-15}$ gave different benzopyran systems.

Pyranobenzopyrans and its derivatives are reported to possess various biological activities such as antibacterial, antifungal, CNS depressant, antiviral, ulcer inhibitor, etc. ${ }^{16-22}$ Suksdorfin and DCK which contain pyranobenzopyran moiety are known to be potent anti-HIV agents. ${ }^{18}$ We therefore would like to report on a simple and efficient protocol for the synthesis of substituted pyranobenzopyran derivatives. In this report we have condensed 4-hydroxycoumarin; 1a, 4,7-dihydroxycoumarin; $\mathbf{1 b}$ and 6-methyl-4hydroxycoumarin 1c with dimethylacetone1,3dicarboxylate $\mathbf{2}$ with a view to obtain novel pyranobenzopyrans for further synthetic endeavours.

*For correspondence

\section{Experimental}

\subsection{Materials}

All solvents and reagents were obtained from commercial sources and were used without purification unless stated.

\subsection{Apparatus}

Elemental analysis was performed using a Heraeus CHN-O rapid analyzer. IR and UV spectra were recorded with a Shimadzu IR-470 spectrometer and UV/Vis Shimadzu 2100 respectively. Melting points were taken on Scientific Melting point apparatus.

\subsection{Representative general procedure for one-pot synthesis of $3 a-c$}

A mixture of 1a $(10 \mathrm{mmol})$ and $2(2.1 \mathrm{~mL}, 12 \mathrm{mmol})$ were refluxed together in the presence of 4 to 5 drops of pyridine for $1 \mathrm{~h}$. After completion of the reaction, as indicated by TLC, the reaction mixture was poured onto crushed ice and stirred for 2-3h. The solid separated was filtered under suction, washed with ice-cold water $25 \mathrm{~mL}$ and then recrystallized from toluene to afford pure product 3a: White coloured solid $(1.42 \mathrm{~g}, 88 \%)$. M.p. $201-202^{\circ} \mathrm{C}$; IR (neat) $v \max 1264,1762,1722$, 1631, 1600, 2908, 2950, 3065, $3111 \mathrm{~cm}^{-1} ;{ }^{1} \mathrm{H}-\mathrm{NMR}$ $\left(\mathrm{CDCl}_{3}, 300 \mathrm{MHz}\right) \delta 3.76(\mathrm{~s}, 3 \mathrm{H}), 3.97(\mathrm{~s}, 2 \mathrm{H}), 6.26$ (s, 1H), 7.26-8.13 (m, 4H) ppm; ESI-MS (m/z) 287 $\left(\mathrm{M}^{+}+\mathrm{H}^{+}\right)$, 255, 227, 122; Anal. Calcd. for $\mathrm{C}_{15} \mathrm{H}_{10} \mathrm{O}_{6}$ : C-62.94; H-3.52. Found: C-62.91; H-3.36. 


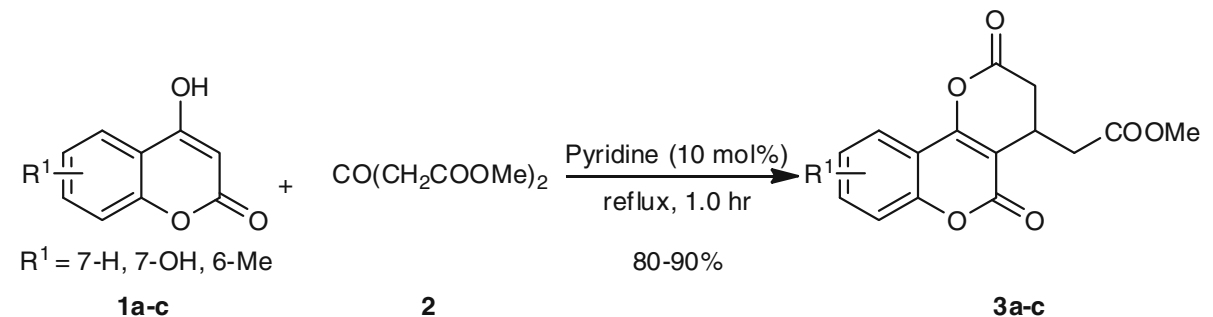

Scheme 1. One-pot synthesis of pyranobenzopyrans.

Table 1. Synthesis of compounds $\mathbf{3 a}-\mathbf{c}$ from $\mathbf{1 a}-\mathbf{c}^{\mathbf{a}}$.

Sl. No.

${ }^{\mathrm{a}} \mathbf{1}(\mathbf{a}-\mathbf{c})(10 \mathrm{mmol})$ and $\mathbf{2}(2.1 \mathrm{~mL}, 12 \mathrm{mmol})$ with Pyridine $(10 \mathrm{~mol} \%)$ refluxed for $1 \mathrm{~h}$.<smiles></smiles>

$R^{1}=H(1 a), M e(1 c)$ a) $\mathrm{CO}\left(\mathrm{CH}_{2} \mathrm{COOMe}\right)_{2} 2$ (1.2 Eq) Pyridine (10 mol\%) reflux, $1.0 \mathrm{hr}$

b) $H N R^{2} R^{3}$ 4a-e (1.2 Eq) $\mathrm{CH}_{3} \mathrm{CN}$, reflux 5-6 hr $60-80 \%$<smiles></smiles>

$\mathbf{5 a}-\mathbf{h} R^{4}=\operatorname{CONR}^{2} R^{3}$

Scheme 2. One-pot synthesis of amide substituted pyranobenzopyrans. 
Table 2. Synthesis of compounds $\mathbf{5 a}-\mathbf{h}$ from $\mathbf{4 a}-\mathbf{e}^{\mathrm{b}}$.

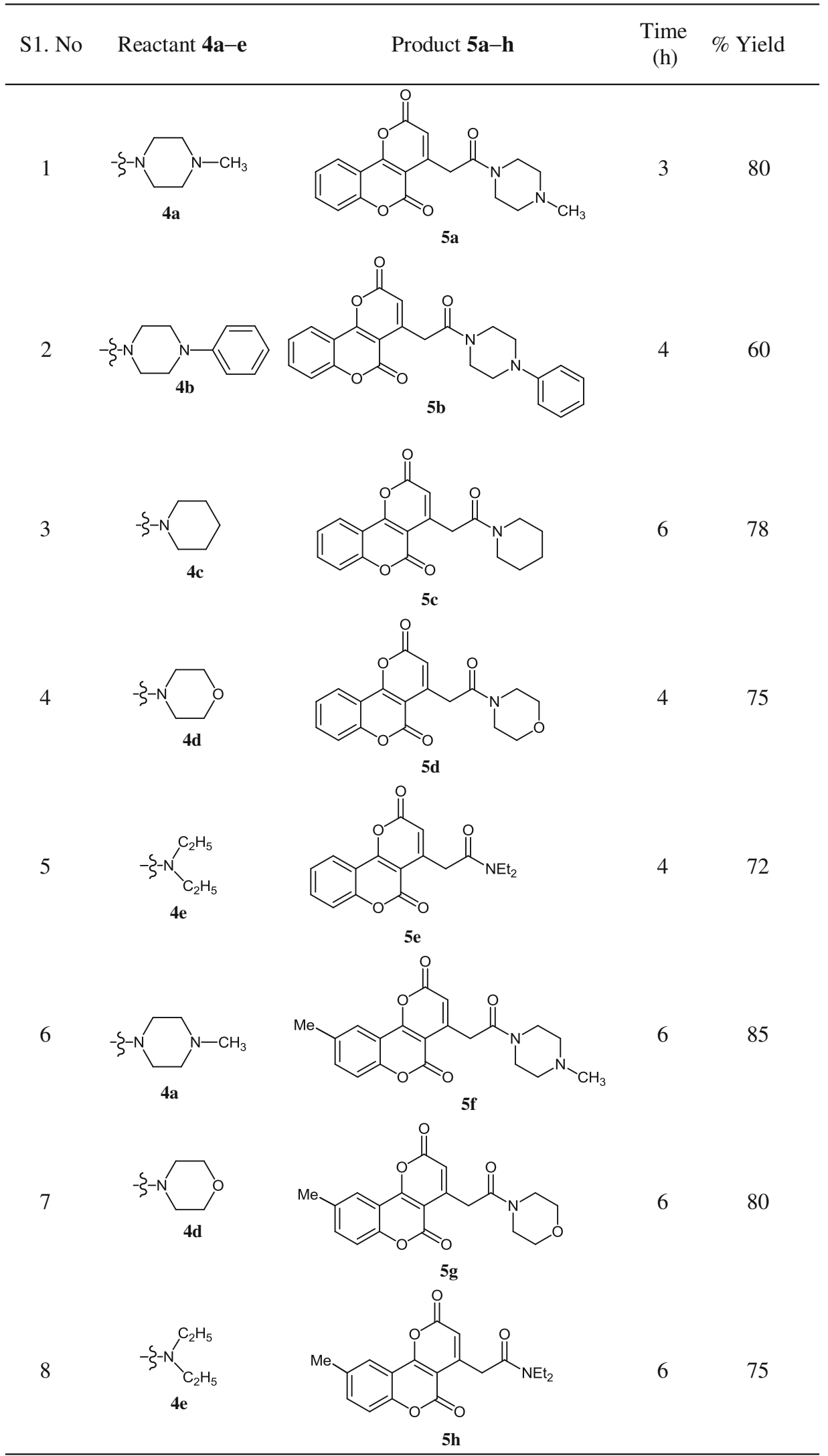

${ }^{\mathrm{b}} \mathbf{1}(\mathbf{a}-\mathbf{c})(10 \mathrm{mmol})$ and $\mathbf{2}(2.1 \mathrm{~mL}, 12 \mathrm{mmol})$ with Pyridine $(10 \mathrm{~mol} \%)$ reflux for $1 \mathrm{~h} . \mathbf{( 4 a - e )}$ (1 mmol) in MeCN $10 \mathrm{~mL}$, refluxed for $4-6 \mathrm{~h}$ 
<smiles></smiles>

$\mathrm{R}^{1}=7-\mathrm{H}(\mathbf{1 a}), 7-\mathrm{OH}(\mathbf{1 b})$, $6-\mathrm{Me}(1 \mathrm{c})$ a) $\mathrm{CO}\left(\mathrm{CH}_{2} \mathrm{COOMe}\right)_{2} 2(1.2 \mathrm{Eq})$ Pyridine (10 mol\%) reflux, $1.0 \mathrm{hr}$

b) $\mathrm{CSNH}_{2}\left(\mathrm{NHNH}_{2}\right) 6 \mathrm{a}(4.0 \mathrm{Eq})$ PPA, $110^{\circ} \mathrm{C}, 4-6 \mathrm{hr}$

$55-65 \%$<smiles></smiles>

$7 a-c$

Scheme 3. Efficient synthetic protocol for thia-diazole.

\subsection{Representative procedure for one-pot synthesis of $\mathbf{5 a} \boldsymbol{h}$}

A mixture of $\mathbf{1 a}(10 \mathrm{mmol})$ and $\mathbf{2}(2.1 \mathrm{~mL}, 12 \mathrm{mmol})$ were refluxed together in the presence of 4 to 5 drops of pyridine for $1 \mathrm{~h}$ until the starting material was completely consumed (monitored by TLC). Then a solution of the secondary amine $4 \mathbf{a}(12 \mathrm{mmol})$ in $\mathrm{CH}_{3} \mathrm{CN} 10 \mathrm{~mL}$ was added and refluxed for $4-6 \mathrm{~h}$ until the conversion was complete (monitored by TLC). A white coloured compound which was formed during the reaction was filtered and washed with water $25 \mathrm{~mL}$. The solid residue was dried and recrystallised from ethanol to afford 5a: White coloured solid (2.23 g 78\%). M.p. $218-220^{\circ} \mathrm{C}$; IR (neat) $v \max 3210,2952,2851,2802,1757,1726 \mathrm{~cm}^{-1}$; Anal. Calcd for $\mathrm{C}_{19} \mathrm{H}_{18} \mathrm{~N}_{2} \mathrm{O}_{5}$ : C-64.40, N-7.56, H-5.99 Found:. C-64.81, N-7.50, H-5.90.

\subsection{Representative procedure for one-pot synthesis of $7 a-c$}

A mixture of 1a $(10 \mathrm{mmol})$ and $2(2.1 \mathrm{~mL}, 12 \mathrm{mmol})$ were refluxed together in the presence of 4 to 5 drops of pyridine for 1 hour until the starting material was completely consumed (monitored by TLC). A mixture of 6a $(1.82 \mathrm{~g}, 20 \mathrm{mmol})$ and $10 \mathrm{~mL}$ of polyphosphoric acid was added and heated for about $3-4 \mathrm{~h}$ at $100-110^{\circ} \mathrm{C}$.

Table 3. Synthesis of compounds $7 \mathbf{a}-\mathbf{c}$ from $1 \mathbf{a}-\mathbf{c}^{\mathrm{c}}$.

S1. No.

${ }^{\mathrm{c}} \mathbf{1}(\mathbf{a}-\mathbf{c})(10 \mathrm{mmol}), 2(2.1 \mathrm{~mL}, 12 \mathrm{mmol})$ with Pyridine $(10 \mathrm{~mol} \%)$ reflux for $1 \mathrm{~h} . \mathbf{6 a}(1.82 \mathrm{~g}$, $20 \mathrm{mmol}$ ) and $10 \mathrm{~mL}$ of polyphosphoric acid was added and reaction stirred for about 4-6 h at $110^{\circ} \mathrm{C}$. 
The progress of the reaction was monitored on TLC. The reaction mixture was then poured into crushed ice and stirred for about $2 \mathrm{~h}$. The solid was filtered under suction. The residue was dried and recrystallised from a mixture of $80 \%$ ethanol and DMF to afford 7a: Cream coloured solid (1.51 g 53\%). M.p. $267-268^{\circ} \mathrm{C}$; IR (neat) $v \max 3227,3060,3040,2896,2960,2825,1787,1721$, $1640 \mathrm{~cm}^{-1}$; ${ }^{1} \mathrm{H}-\mathrm{NMR}\left(\mathrm{DMSOd}_{6}, 300 \mathrm{MHz}\right) \delta 3.01$ (s, 2H), $6.42(\mathrm{~s}, 1 \mathrm{H}), 7.31-8.52(\mathrm{~m}, 4 \mathrm{H}), 7.90-8.11$ (s, 2H) ppm; EI-MS (m/z) $327\left(\mathrm{M}^{+}\right), 227,198,170$. Anal. Calcd for $\mathrm{C}_{16} \mathrm{H}_{11} \mathrm{~N}_{3} \mathrm{O}_{4} \mathrm{~S}$ : C-55.04, N-12.84, S9.80, H-2.77. Found: C-55.37, N-12.65, S-9.76, H-2.52. See Supplementary information for complete characterization and experimental details of the remaining analogs.

\section{Results and discussion}

The condensation of $\beta$-ketoesters with phenolic compounds in the presence of concentrated sulfuric acid is called Pechmann reaction. ${ }^{23}$ Various lewis acid catalysts have also been employed in the past for this purpose. Base catalysed condensation has also been reported. ${ }^{24}$ In the present investigation an attempt has been made to synthesize pyranobenzopyrans $\mathbf{3 a}-\mathbf{c}$ by condensing substituted 4-hydroxycoumarins 1a-c with dimethylcetone1,3-dicarboxylate. For this purpose, we first employed various catalysts like concentrated sulfuric acid, aluminium trichloride but no conversion to the desired product was observed with only starting material being recovered. The reaction was then performed using a base catalyst such as pyridine, in the presence of various solvents like ethanol and ethyl acetate but the reaction time was very long with poor yields. On the other hand, simply mixing and refluxing the two reactants together neatly, in the presence of catalytic amount of pyridine $(10 \mathrm{~mol} \%)$ resulted in the formation of compound 3a-c in good yields (scheme 1, table 1).

With the desired pyranobenzopyrans 3a-c in hand, we initially set out to test the reactivity of the active methylene group by performing Mannich and Knoevenagel reactions on it. But the conversions to desired product were not effected indicating the inactivity of the moiety. The reactivity of the ester group was then tested by condensing pyranobenzopyrans $\mathbf{3 a}$ and $\mathbf{3 c}$ with various secondary amines to synthesize substituted amides $\mathbf{5 a}-\mathbf{h}$ in good to excellent yields (scheme 2, table 2).

The synthesis of amides from esters in general could be effected using trialkylaluminium or under vigorous conditions with a strong base and higher temperature. ${ }^{25,26}$ Microwave heating has also been employed for the synthesis of amides from esters. ${ }^{27}$ Here we have presented a simple protocol for the conversion of esters into amides at ambient temperature using a mild base such as pyridine. It was observed that the ester group was extremely reactive and various secondary amines (4a-e) could be condensed on to pyranobenzopyrans in good yields. Also different pyranobenzopyrans 3a-c could be condensed with $\mathbf{6 a}$ to give the cyclized products $7 \mathbf{a}-\mathbf{c}$. One pot reactions are more efficient than the conventional methods as they reduce the time and energy required for the work-up and isolation of the product, thus adhering to green chemistry principles. ${ }^{28}$ Since we were able to isolate and characterize $\mathbf{3 a}$ and $\mathbf{3 c}$ as well as their various derivatives, we tried to improve the efficiency of the process by carrying out one-pot reaction (schemes 2 and 3, tables 2 and 3).

\section{Conclusion}

In summary, we have developed a sequential one-pot reaction for the synthesis of a variety of substituted benzopyrans using simple chemistry that would save time and resources thereby making the process efficient and environmentally benign. The simplicity, ease of workup, together with the use of inexpensive and efficient base catalyst, is the notable feature of this procedure.

\section{Supplementary information}

The electronic supplementary information can be seen in www.ias.ac.in/chemsci.

\section{Acknowledgements}

Authors are thankful to Ramnarain Ruia College for providing research facilities and University Grants Commission (UGC) for funding.

\section{References}

1. Cravotta G, Nano G M, Palmisano G and Tagliapietra S 2003 Synthesis 1286

2. Stahmann A, Ikawa M and Link K P 1948 Chem. Abstr. $42 \mathrm{P} 603 \mathrm{H}$

3. Emmanuel-Giota A A, Fylaktakidou K C, HadjipavlouLitina D J, Litinas K E and Nicolaides D N 2001 J. Het. Chem. 38717

4. Kontogiorgis C and Litina H D 2003 J. Enzym. Med. 18 63

5. Marcu M G, Schulte W T and Neckers L 2000 J. Natl. Cancer Inst. 92242

6. Nofal Z M, El-Zahar M I and Abd El-Karim S S 2000 Molecules 599 
7. Raev L, Voinov E, Ivanov I and Popov D 1990 Pharmazie $\mathbf{4 5} 696$

8. Tripathi A K, Mukherjee D, Koul S and Taneja S C 2009 ARKIVOC 8241

9. Yoon Y, Kim Y O, Lim N Y, Leon W Y and Sung H J 1999 Planta Medica 65532

10. Kerr J F R, Wyllie H A and Currie A R 1972 Br. J. Cancer 26239

11. Dini L 2005 Tissue Cell 37379

12. Rello S, Stockert J C, Moreno V, Gamez A, Pacheco M, Juarranz A, Canete M and Villanueva A 2005 Apoptosis 10201

13. Talapatra S K, Das P K, Chakrabarti R, Mukhopadhyay P K and Talapatra B 1984 Heterocycles 18519

14. Talapatra B, Mandal S K, Biswas K, Chakrabarti R and Talapatra S K 2001 Indian J. Chem. Soc. 78 765

15. Yoshio I, Masatashi M, Noboru H, Tatsuya M, Yoichi K and Toshiyuki M 2001 Synth. Commun. 31439

16. Arora R B and Mathur C N 1963 Brit. J. Pharmacol. Chemother. 2029
17. Balbi A, Sottofattori E, Grandi T, Mazzei M, Abramova T V, Lokhov S G and Lebedev A V 1994 Tetrahedron 50 4009

18. Xie L, Takeuchi Y, Mark C L and Lee K 1999 J. Med. Chem. 422662

19. Reet G V and Heeres J 1979 U. S. Pat. 4160838

20. Burch H A and Smith W O 1966 J. Med. Chem. 9405

21. Mir I, Siddique M T and Comric A 1970 Tetrahedron 26 5235

22. Hu Z Q, Yang Y X, Shang Y Q, Zhou K and Xu L Z 2006 Acta Cryst. E62 3457

23. Joule J A and Mills K 2000 Heterocyclic chemistry, 4th edition, Oxford, UK: Blackwell Science

24. Ohberg L and Wesman J 2001 Synlett. 81296

25. Lipton M F, Basha A, Weinreb S M 1999 Org. Synth. 6 492

26. Wang W B, Roskamp E J 1992 J. Org. Chem. 576101

27. Arora R, Paul S, Gupta R 2005 Can J. Chem. 831137

28. Tietze L F 1996 Chem. Rev. 96 115; (b) Tietze L F, Brasche G, Gericke K M 2006 Domino reactions in organic synthesis, Weinheim: Wiley-VCH 